\title{
Akhlak Mulia dalam Pandangan Masyarakat
}

\author{
Mustopa \\ IAIN Walisongo Semarang \\ E-mail: halmar66@gmail.com
}

\begin{abstract}
This paper elaborate on views of the community on a noble character. Categorization of noble character is different in view of the public. This study used a qualitative approach which is the data derived from the literature and society. The results of this study indicate that the noble character in view of the public looks through oral and actions and it is always behaved by someone, and it is not temporary. Normative morality is embedded in the inner nature of the soul that gives rise to act with ease. Morals reflected in a person in relation to God and the community. It was influenced by heredity, environment, and both formal and non-formal education. Individually, moral goodness cause calmness and serenity in a person and make it easier to interact socially with the community.
\end{abstract}

Keywords: noble character, community

\begin{abstract}
Abstrak
Tulisan ini menguraikan pandangan masyarakat tentang akhlak mulia. Kategorisasi akhlak mulia berbeda-beda dalam pandangan masyarakat. Penelitian ini menggunakan pendekatan kualitatif yang sumber datanya berasal dari literatur dan masyarakat. Hasil kajian ini menunjukkan bahwa akhlak mulia dalam pandangan masyarakat tampak melalui lisan dan perbuatannya dan selalu ada pada seseorang, dan tidak bersifat temporer. Akhlak secara normatif merupakan sifat batin yang tertanam dalam jiwa yang memunculkan perbuatan dengan mudah. Akhlak terpantul dalam diri seseorang dalam hubungannya dengan Tuhan dan masyarakat. Hal itu dipengaruhi keturunan, lingkungan, dan pendidikan baik formal maupun nonformal. Secara individual, kebaikan akhlak menyebabkan ketenangan dan ketenteraman pada diri seseorang dan secara sosial memudahkan berinteraksi dengan masyarakat.
\end{abstract}

Kata kunci: akhlak mulia, masyarakat 


\section{A. Pendahuluan}

Misi utama diutus Rasulullah Muhammad SAW adalah untuk menyempurnakan akhlak mulia, "Sesungguhnya saya diutus untuk menyempurnakan akhlak mulia". Sebagaimana dijelaskan dalam firman-Nya (Q.S. Ibrahim/14 : 1) "Alif Lam Ra. (Ini adalah) Kitab yang Kami turunkan kepadamu (Muhammad) agar engkau mengeluarkan manusia dari kegelapan kepada cahaya terangbenderang dengan izin Tuhan". Menurut Quraish Shihab, "mengeluarkan manusia dari kegelapan kepada cahaya", artinya mengeluarkan manusia seluruhnya dari aneka gelap gulita, apapun bentuk dan jenisnya, termasuk akhlak yang tercela manusia. ${ }^{1}$

Seorang dapat dikatakan berakhlak, apabila ia mendasarkan perilakunya pada ajaran agama Islam, yang bersumber pada wahyu. Ia menunjukkan kesadaran terhadap keberadaan Tuhan di setiap saat, menyadari bahwa Tuhan mengetahui segala perbuatannya. Sehingga segala aktivitas hidupnya adalah untuk beribadah kepada Allah. Jadi, keimanan dalam Islam, pada dasarnya merupakan kesadaran untuk menjadi pribadi yang baik. ${ }^{2}$ Maka, di sinilah letak hubungan antara akhlak dan iman.

Hubungan akhlak dengan ibadah dapat dilihat dalam pengajaran prinsip-prinsip Islam beserta pengamalannya. Prinsipprinsip yang dimaksud adalah rukun Islam yang lima, dengan melaksanakan rukun tersebut, otomatis dapat mengembangkan akhlaknya. ${ }^{3}$ Dengan berpegang pada syahadah, seorang Muslim akan komit untuk taat kepada Allah. Implikasinya, ia akan menunjukkan integritas, kejujuran, amanah dan sebagainya. Begitu pula salat, seorang Muslim akan terhindar dari perbuatan keji, sederhana, ramah dan sebagainya. Implikasinya akan terlihat dalam hubungan seseorang dengan kedua orang tua, keluarga, tetangga, semua orang termasuk dengan binatang dan alam. Dengan menjalankan rukun Islam ketiga yaitu zakat, seorang Muslim akan dapat menanamkan benih-benih kebajikan, simpati dan kedermawanan untuk mengokohkan hubungan persahabatan

1 M. Quraish Shihab, Tafsir Al-Misbah, (Tangerang: Lentera Hati, 2005), jil. 7, hlm. 6 .

${ }^{2}$ Al-Gazali, Ihyä' Ulüm al-Dīn, juz 1,terj. Ismail Ya'kub, (Singapura: Pustaka Nasional, 2003), hlm. 3.

${ }^{3}$ Al-Gazali, Ihyà' Ulüm al-Dìn, juz 1, hlm. 1. 
berdasarkan cinta kasih. Selain itu, dalam puasa dan haji, dapat mendidik orang untuk bersabar, menahan diri dan disiplin diri. ${ }^{4}$

Ibadah dalam praktiknya telah memiliki ketentuan yang jelas cara melakukannya, terutama yang berhubungan dengan syarat rukun. Sehingga dapat dijadikan ukuran pada praktik ibadah yang baik dan benar. Namun, tidak demikian pada akhlak. Akhlak yang notabene merupakan sifat dari jiwa yang menimbulkan perbuatan tanpa melalui pemikiran dan pertimbangan, belum dapat diketahui dengan pasti tentang hukum perbuatannya, sebelum diadakan penelitian terhadap suatu perbuatan. Di samping itu, praktik "perbuatan" akhlak, sangat mungkin terjadi perbedaan antara satu orang dengan orang lain. Misalnya, perbedaan dalam mengukur nilai perbuatan yang baik dan buruk, dapat menyebabkan perbedaan dalam merespons keadaan yang dihadapi. Perbedaan dalam mengukur perbuatan akhlak muncul, sebab adanya perbedaan pandangan antara satu dengan yang lainnya. Sehingga akan terjadi perbedaan antara satu sama lain.

Bahasan tentang akhlak mulia lebih banyak berdasarkan kajian-kajian normatif-deduktif, menurut para ulama atau pakar, dan masih jarang adanya kajian yang berdasarkan pengalaman empirik dalam masyarakat dengan pendekatan induktif. Kajian berdasarkan pendekatan empirik-induktif tersebut, diharapkan akan dapat memudahkan sosialisasi mengenai akhlak mulia, yang notabene merupakan tujuan utama dari misi diutusnya Nabi Muhammad saw.

\section{B. Metode Penelitian}

Penelitian ini bertujuan untuk mendapatkan gambaran tentang pandangan masyarakat terhadap akhlak mulia melalui pendekatan kualitatif. Data dikumpulkan dari latar yang alami sebagai sumber data langsung. Penelitian ini diharapkan mampu menemukan, sekaligus mendeskripsikan data secara menyeluruh dan utuh, berkaitan pandangan masyarakat tentang akhlak mulia. Selain itu, penelitian ini juga diharapkan mampu membangun suatu teori secara induktif dari berbagai abstraksi data yang telah

${ }^{4}$ Hamid Fahmy Zarkasy, Peranan Masjid dalam Pendidikan Karakter (Akhlaq), (Semarang: Makalah Seminar Masjid Baiturrahman, 2011), hlm. 12. 
dikumpulkan tentang akhlak yang mulia, melalui temuan makna dalam latar yang alami oleh masyarakat.

Data yang dikumpulkan dalam penelitian ini sesuai dengan tujuan penelitian, yaitu pandangan masyarakat tentang akhlak mulia. Jenis data dalam penelitian ini dibedakan menjadi dua, yaitu data primer dan sekunder. Data primer diperoleh dalam bentuk verbal atau kata-kata atau ucapan lisan dari subjek (informan) yang berkaitan dengan pandangan masyarakat terhadap akhlak mulia. Data sekunder bersumber dari dokumen-dokumen dan bendabenda, yang digunakan sebagai pelengkap data primer, seperti literatur terkait pandangan masyarakat tentang akhlak mulia.

Sumber data dalam penelitian ini adalah manusia atau orang yang bertindak sebagai subjek atau informan kunci (key informants). Penentuan informan dalam penelitian ini didasarkan pada kriteria berikut: 1) Subjek cukup lama dan intensif menyatu dengan medan aktivitas yang menjadi sasaran penelitian. 2) Subjek masih aktif terlibat di lingkungan yang menjadi sasaran penelitian ini. 3) Subjek yang masih memiliki waktu untuk dimintai informasi oleh peneliti. Sehubungan dengan kriteria yang sesuai dengan tujuan penelitian tersebut, maka pemilihan informan peneliti dilakukan dengan memilih subjek yang dianggap cukup mewakili pandangan masyarakat. Dan peneliti memilih subjek yang dianggap menjadi tokoh di masyarakatnya.

Demi memperoleh data secara holistik dan integratif, serta memperhatikan relevansi data dengan tujuan penelitian. Maka dalam pengumpulan data penelitian menggunakan teknik studi literatur dan wawancara. Teknik studi literatur digunakan untuk mengetahui konsep akhlak mulia secara normatif. Sedangkan teknik wawancara digunakan untuk mendapatkan data yang diperlukan dalam penelitian, yaitu pandangan masyarakat tentang akhlak mulia. Teknik wawancara berupa wawancara terstandar (standardized interview), peneliti menyusun suatu daftar pertanyaan secara tertulis, dan diberikan kepada subjek penelitian sebelum dilakukan wawancara.

Menurut Bodgan dan Biklen dalam Madyo Ekosusilo, ${ }^{5}$ analisis data merupakan proses mencari dan mengatur secara

${ }^{5}$ Madyo Ekosusilo, Sistem Nilai Dalam Budaya Organisasi Sekolah pada Sekolah Unggul (Studi Multi Kasus di SMU Negeri 1, SMU Regina 
sistematis transkrip wawancara, catatan lapangan, dan bahanbahan lain yang telah dihimpun oleh peneliti. Analisis dilakukan dengan menelaah data, menata, membagi menjadi satuan-satuan yang dapat dikelola, menyintesis, mencari pola, menemukan apa yang bermakna, apa yang diteliti dan dilaporkan secara sistematis. Data merupakan deskripsi dari pertanyaan-pertanyaan seseorang tentang perspektif, pengalaman atau suatu hal, sikap, keyakinan, dan pikirannya serta petikan-petikan isi dokumen yang berkaitan dengan suatu program. ${ }^{6}$

Setelah data terkumpul, kemudian diadakan analisis data. Menurut Miles dan Huberman dalam Sugiyono bahwa analisis data terbagi menjadi beberapa tahap, yaitu: 1) data reduction, yaitu merangkum, memilih hal-hal pokok, memfokuskan hal-hal penting dari tema dan polanya serta membuang yang tidak perlu. Pada tahap awal ini, peneliti berusaha mendapatkan data berdasarkan masalah dan tujuan penelitian yang telah ditetapkan. 2) tahap data display atau penyajian data, dalam penelitian kualitatif biasanya berupa teks yang bersifat naratif, dan bisa dilengkapi dengan grafik, matrik, network dan chart. Pada tahap ini peneliti menyajikan data berkaitan dengan pandangan masyarakat tentang akhlak mulia. 3) Conclusion drawing atau verification, yakni tahap penarikan kesimpulan dan verifikasi. Pada tahap ini diharapkan peneliti sudah mampu menjawab rumusan tujuan penelitian yaitu pandangan masyarakat tentang akhlak mulia. ${ }^{7}$

\section{Konsep Akhlak Mulia}

Secara bahasa Akhlak, (Bahasa Arab: akhlāq) berarti bentuk kejadian; dalam hal ini tentu bentuk batin seseorang. ${ }^{8}$ Kata $a k h l \bar{q} q$ merupakan bentuk jama' dari kata khuluq. Dalam Kamus alMunjid, kata khuluq berarti budi pekerti, perangai, tingkah laku, atau tabiat. ${ }^{9}$ Begitu pula, dalam bahasa Yunani, pengertian khuluq

Pacis, dan SMU Al-Islam 01 Surakarta), (Disertasi: Universitas Negeri Malang, 2003), hlm. 81.

${ }^{6}$ Ekosusilo, Sistem Nilai ..., hlm. 81-82.

7 Sugiyono, Metode Penelitian Pendidikan: Pendekatan Kuantitatif, Kualitatif dan R\&D, (Bandung: Alfabeta, 2008), hlm. 247.

8 Murni Jamal, Metodik Khusus Pengajaran Agama Islam, (Jakarta: Departemen Agama, 1984), hlm. 53.

${ }^{9}$ Luis Ma'luf, Al-Munjid, (Bairut: Dar al-Masyriq, t.t.), hlm. 194. 
ini disamakan dengan kata ethicos, yang berarti adab kebiasaan, perasaan batin, kecenderungan hati untuk melakukan perbuatan. Ethicos kemudian berubah menjadi etika. ${ }^{10}$ Kata khuluq disebutkan dalam al-Qur'an Surat al-Qalam/68 ayat 4, yang artinya "Dan Sesungguhnya kamu benar-benar berbudi pekerti yang agung". Firman Allah tersebut menunjukkan bahwa kata khuluq merupakan perilaku Rasulullah Saw. yang telah menjadi kebiasaan. Menurut Quraish Shihab, kata khuluq dalam ayat tersebut jika tidak dibarengi dengan objektifnya, maka berarti budi pekerti yang luhur, tingkah laku dan watak terpuji. ${ }^{11}$

Perilaku-perilaku Rasulullah Saw. yang telah menjadi kebiasaan disebut dengan akhlāq (Indonesia: akhlak). Rasulullah Saw. diutus untuk menyempurnakan akhlak yang mulia, dan akhlak beliau adalah al-Qur'an. Beliau mengajarkan kita untuk berdoa ketika bercermin; "Allāhummā kamā hassanta khalqī, fahassin khuluq१”", yang artinya ialah "Ya Allah sebagaimana telah Engkau baguskan penciptaanku ini, maka baguskan pula akhlak ini". Dalam doa tersebut terkandung maksud bahwa kita memohon kepada Allah agar diberi kemudahan untuk memperoleh akhlak yang baik. Dan pernyataan bahwa pemberian Allah kepada kita berupa penciptaan pada diri ini adalah benar-benar yang terbaik (Q.S. Al-Tin/95: 4).

Definisi akhlak dapat dirujuk dari beberapa pengertian para tokoh, seperti al-Gazali, Abdullah Darroz, Ibnu Maskawaih, dan Ahmad Amin. Menurut Imam Al-Gazali, akhlak adalah sifat yang tertanam dalam jiwa yang dapat menimbulkan perbuatanperbuatan dengan mudah tanpa melalui pemikiran dan pertimbangan. $^{12}$

Menurut Abdullah Darroz, akhlak adalah suatu kekuatan dalam kehendak yang mantap serta membawa kecenderungan terhadap pemilihan pada pihak yang benar (akhlak yang baik) dan/atau pihak yang jahat (akhlak yang buruk). ${ }^{13}$ Menurut Ahmad Amin, akhlak adalah kebiasaan kehendak, yang berarti bahwa bila kehendak itu membiasakan sesuatu maka kebiasaan tersebut

${ }_{10}$ M. Yatimin Abdullah, Studi Akhlak dalam Perspektif Al-Qur'an, (Jakarta: Amzah, 2007), hlm. 3.

${ }^{11}$ Shihab, Tafsir Al-Misbah, jil. 14, hlm. 380.

${ }^{12}$ Al-Gazali, Ihyä' Ulüm al-Dìn, hlm, 1034.

${ }^{13}$ Abdullah, Studi Akhlak ..., hlm. 4. 
disebut akhlak. ${ }^{14}$ Akan tetapi, Ahmad Amin memberikan pengertian yang lain, akhlak ialah menangnya keinginan dari beberapa keinginan manusia secara langsung dan berturut-turut. Dinamakan orang yang (berakhlak) baik adalah orang yang menguasai keinginan baik dengan langsung dan berturut-turut, sebaliknya orang yang (berakhlak) buruk ialah orang yang menguasai keinginan buruk dengan langsung dan berturut-turut. ${ }^{15}$ Sedangkan menurut Ibn Maskawaih, akhlak adalah suatu keadaan yang melekat pada jiwa manusia, yang berbuat dengan mudah, tanpa melalui pemikiran atau pertimbangan. ${ }^{16}$

Berdasarkan definisi akhlak di atas, penulis menganggap pengertian akhlak menurut al-Gazali memiliki kesamaan dengan Ibn Maskawaih. Keduanya sama-sama menyebutkan akhlak sebagai keadaan yang melekat pada jiwa, yang menjadikan manusia dapat berbuat dengan mudah, tanpa melalui pemikiran dan pertimbangan. Adapun pengertian akhlak menurut Ahmad Amin bersifat lebih umum, yakni akhlak ialah kehendak yang dibiasakan. Sehingga kalau kehendaknya membiasakan perbuatan, dan perbuatannya menjadi terbiasa, maka dinamakan akhlak pula.

Dilihat dari segi redaksinya, pengertian-pengertian tersebut memiliki kemiripan, antara definisi dari kedua tokoh di atas (alGazali dan Ibn Maskawih) dan Ahmad Amin. Namun, perbedaannya ialah dalam Ahmad Amin tidak menyebutkan keadaan perbuatan yang muncul, apakah melalui pemikiran dan pertimbangan atau tidak. Hanya saja Amin, juga mengatakan bahwa akhlak ialah menangnya keinginan dari beberapa keinginan manusia dengan langsung dan berturut-turut. Kata keinginan manusia dengan langsung dan berturut-turut, memberikan pemahaman bahwa perbuatan tersebut telah menjadi terbiasa. Adapun pengertian yang lain, pasti memiliki kesamaan dengan pengertian yang dikemukakan oleh ketiga tokoh di atas. Selanjutnya, penulis menggunakan pengertian akhlak menurut Ibn Maskawaih dan al-Gazali. Akhlak adalah sifat yang tertanam dalam jiwa yang melahirkan perbuatan dengan mudah tanpa melalui pemikiran dan pertimbangan. Maksud dari sifat yang

${ }^{14}$ Ahmad Amin, Etika (Ilmu Akhlak), (Jakarta: Bulan Bintang, 1993), hlm. 62 .

${ }^{15}$ Amin, Etika ..., hlm. 62.

${ }^{16}$ Ibn Maskawaih, Kitab Tahżib al-Akhlaq wa Tațir al-A'raq, (Mesir: al-Husainiyah al-Misriyah,1329 H), hlm. 25. 
tertanam dalam jiwa yakni salah satunya berupa kehendak, sebagaimana menurut Ahmad Amin.

Konsep akhlak al-Gazali memiliki kesamaan dengan konsep Ibnu Maskawaih, terutama tentang pengertian akhlak. Konsep akhlak tersebut dapat dilihat dari karya keduanya, yaitu al-Gazali dalam Ihyä, Ulum al-Din dan Ibnu Maskawaih dalam Kitab Tahżib al-Akhläq wa Tathir al-A'raq. Kesamaan konsep keduanya tentang akhlak, menarik untuk ditanggapi, siapa yang merujuk pendapat siapa. Apakah Maskawaih merujuk pendapat al-Gazali, ataukah sebaliknya? Jika dilihat dari riwayat hidup kedua tokoh tersebut, Ibnu Maskawaih lahir lebih dahulu daripada al-Gazali. Menurut Abu Ali, seorang pengkaji dan sejarawan, Ibnu Maskawaih lahir di Ray, menetap di Isfahan, dan wafat di kota tersebut pada tahun 421 H./1030 M. ${ }^{17}$ Sedangkan al-Gazali, yang lahir di kota Thusia (Toos) Khurasan tahun 1058 M./450 H, dan wafat tahun $1111 \mathrm{M} . / 505 \mathrm{H} .{ }^{18}$ Maka jika dilihat dari sejarah hidup, al-Gazali lahir setelah 28 tahun dari wafatnya Ibnu Maskawaih.

Dengan demikian, maka al-Gazali lah yang merujuk pendapat Ibnu Maskawaih. Ibnu al-Khatib, dalam kata pengantar penerbitan buku Kitab Tahżib al-Akhläq wa Tathir al-A'raq, ia mengakui bahwa setelah membaca buku karya Ibn Maskawaih, mengira bahwa Ibnu Maskawaih banyak merujuk pendapat al-Gazali. ${ }^{19}$ Hal ini dikarenakan ia menemukan banyak kesamaan dengan isi kitab Ihyā' Ulum al-Din karya al-Gazali. Tetapi setelah melihat sejarah hidup kedua tokoh tersebut, ternyata Maskawaih lebih dahulu lahir daripada al-Gazali, bahkan beliau lahir jauh setelah Ibn Maskawaih wafat. Berdasarkan realitas tersebut, Ibnu alKhatib mengatakan, al-Gazalilah yang merujuk pada Ibn Maskawaih.

Berdasarkan pengertian akhlak di atas, dapat dipahami bahwa akhlak memiliki beberapa indikator, yaitu: Pertama, pada dasarnya akhlak adalah perbuatan lahiriah yang menunjukkan keadaan jiwa. Perbuatan lahiriah yang ditampilkan merupakan tanda atau gejala adanya akhlak. Sebab, keadaan jiwa tidak dapat dibuktikan kecuali dengan melihat gejala yang dilahirkan. Akhlak merupakan sifat dalam diri seseorang yang mendorong lahirnya perbuatan-

${ }^{17}$ Ibnu Maskawaih, Menuju Kesempurnaan Akhlak, terj Helmi Hidayat, (Bandung: Mizan, 1997), hlm. 29.

${ }^{18}$ Al-Gazali, Ihya', Ulüm al-Dīn, juz I, hlm. 25.

${ }^{19}$ Maskawaih, Menuju Kesempurnaan Akhlak ..., hlm. 26. 
perbuatan, dan jika sifat tersebut dibiasakan maka akan melahirkan perbuatan dengan mudah tanpa melalui pertimbangan dan pemikiran, dan perbuatan tersebut akan menjadi kebiasaan.

Oleh karena itu, untuk mengetahui akhlak seseorang, dapat dilihat dari perbuatan yang ditampilkan. Sebab, perbuatan yang terlihat sebenarnya merupakan ekspresi dari sifat batinnya. Sehingga kalau perbuatan yang ditampilkan adalah baik, maka menunjukkan sifat yang tertanam dalam jiwa adalah baik. Begitu juga sebaliknya, jika perbuatan yang ditampilkan adalah perbuatan yang buruk, maka hal ini menunjukkan bahwa sifat dalam jiwa pun juga buruk. Pertanyaannya ialah apakah setiap perbuatan yang ditampilkan seseorang pasti menunjukkan sifat batin yang asli atau akhlak seseorang? Jawabannya, bahwa tidak selalu perbuatan yang ditampilkan dapat menunjukkan keadaan akhlak seseorang, karena harus dilihat cara munculnya perbuatan tersebut, apakah munculnya itu secara mudah, ataukah karena telah melalui pemikiran dan pertimbangan.

Indikator yang kedua, yakni perbuatan akhlak tersebut ialah secara mudah dan tanpa melalui pemikiran dan pertimbangan. Kalau suatu perbuatan itu muncul melalui pemikiran dan pertimbangan terlebih dahulu. Sehingga tidak akan mudah muncul, walaupun perbuatan tersebut bernilai baik, tetapi belum dapat dikatakan sebagai akhlak, karena masih dalam proses (perbuatan) akhlak.

Ketiga, Perbuatan yang dibiasakan atau telah menjadi kebiasaan. Perbuatan yang menunjukkan adanya akhlak adalah perbuatan yang telah menjadi kebiasaan. Perbuatan yang belum dibiasakan tidak dikatakan sebagai akhlak tapi masih dalam 'proses' (perbuatan) akhlak. Menurut penulis, perbuatan yang dilakukan secara terus-menerus akan menjadi perbuatan yang terbiasa dan akan muncul dengan mudah. Dengan alasan, bahwa akhlak merupakan kebiasaan kehendak, sebagaimana kata Ahmad Amin. ${ }^{20}$ Kehendak untuk melakukan perbuatan itu, jika dibiasakan secara terus-menerus akan menjadi perbuatan yang terbiasa dengan mudah. Oleh sebab itu, perbuatan yang terbiasa berawal dari perbuatan yang dilakukan secara terus-menerus.

Di samping itu, penulis mengutip pengertian akhlak menurut al-Gazali, akhlak adalah sifat yang tertanam dalam jiwa yang

${ }^{20}$ Ahmad Amin, Etika ..., hlm. 62. 
menimbulkan perbuatan-perbuatan dengan mudah tanpa melalui pemikiran dan pertimbangan. ${ }^{21}$ Menurut penulis, timbulnya perbuatan dengan mudah tanpa melalui pemikiran dan pertimbangan tersebut, dapat terjadi karena perbuatan tersebut telah terbiasa dilakukan, melalui proses secara kontinu, dan pada akhirnya perbuatan itu menjadi mudah dilakukan. Oleh karena itu, perbuatan yang telah terbiasa dilakukan, maka akan muncul secara mudah bilamana dibutuhkan pada kesempatan lain, seolah-olah tanpa melalui pemikiran dan pertimbangan.

Keempat. Perbuatan akhlak dilakukan berdasarkan kesadaran. Munculnya perbuatan dengan mudah tanpa melalui pemikiran dan pertimbangan, bukan berarti perbuatan-perbuatan itu dilakukan tanpa sadar, tetapi tetap berdasarkan kesadaran. ${ }^{22}$ Dengan alasan bahwa perbuatan yang terbiasa dilakukan seseorang secara terusmenerus, akan menjadikan seseorang melakukan dengan mudah, sehingga karena kemudahan tersebut 'seolah-olah' dilakukan tanpa melalui pemikiran dan pertimbangan.

Penulis mengatakan 'seolah-olah', sebab pada dasarnya seseorang melakukan perbuatan pasti sebelumnya telah dipertimbangkan dan dipikirkan. Inilah yang membedakan perbuatan yang dilakukan oleh seseorang dengan binatang. Namun, karena telah terbiasa melakukan perbuatan tersebut secara terus-menerus, maka menjadi mudah dikerjakan, tanpa melalui pemikiran dan pertimbangan.

Sehingga dapat diambil kesimpulan bahwa akhlak sebenarnya merupakan bentuk batin seseorang, di mana untuk mengetahuinya dapat dilihat dari perilaku-perilaku yang ditampilkan, dan proses munculnya perilaku, telah dijelaskan di atas. Sehingga dalam menilai akhlak seseorang, dapat dilihat dari tingkah laku yang ditampilkan. Selain itu dari segi nilai, bentuk batin, ada yang baik dan buruk, serta terpuji dan tercela. Norma baik dan buruk (terpuji dan tercela) bagi orang beriman yang meyakini kebenaran ajaran agama Islam, merupakan ajaran agama sendiri. Bila tingkah laku yang ditimbulkan oleh akhlak itu sesuai dengan ajaran agama Islam, itu dianggap baik, dan apabila bertentangan, maka dianggap buruk atau tercela. ${ }^{23}$ Jadi, baik dan buruknya akhlak dapat dilihat

${ }^{21}$ Al-Gazali, Ihya' 'Ulüm al-Dī, hlm, 1034.

${ }^{22}$ Al-Gazali, Ihyā' 'Ulüm al-Dìn, hlm, 1034.

${ }^{23}$ Zakiah Daradjat, Metodik Khusus Pengajaran Agama Islam, (Jakarta: Bumi Aksara, 2008), hlm. 68. 
dari kesesuaian dengan ajaran Islam. Maka dari itu, akhlak dibagi menjadi dua, yaitu akhlak yang baik (mulia), disebut akhlak mahmüdah dan akhlak yang buruk (tercela), disebut akhlak mażmümah.

Adapun objek akhlak dalam Islam meliputi berbagai aspek hubungan. Menurut Zakiah Daradjat, orang berbuat dalam rangka hubungannya dengan Tuhan, dengan dirinya sendiri, dengan sesama manusia, dengan binatang, dan dengan makhluk lainnya. ${ }^{24}$ Sementara itu, Wahbah az-Zuhaili membagi akhlak muslim menjadi tiga, yaitu hubungan manusia dengan Tuhan, hubungan manusia dengan sesama dan alam semesta, dan hubungan manusia dengan masyarakat. ${ }^{25}$

\section{Pandangan Masyarakat tentang Akhlak Mulia}

Kajian tentang akhlak mulia didasarkan pada pendekatan normatif, dengan melihat akhlak berdasarkan dalil-dalil dan pemikiran para ahli dalam bidangnya. Selanjutnya, dalam pembahasan ini akan mengulas akhlak mulia secara pendekatan induktif berdasarkan pandangan masyarakat. Hal ini menjadi penting agar akhlak dapat mudah disosialisasikan dan dilaksanakan sesuai dengan perkembangan zaman. Sehingga penulis akan memaparkan pandangan masyarakat terhadap akhlak yang mulia.

Paparan berdasarkan hasil wawancara dengan tiga responden yang dipandang sebagai tokoh di masyarakat. Tujuan wawancara adalah untuk mendapatkan data tentang pandangan masyarakat terhadap akhlak mulia yang meliputi: Pengertian akhlak mulia, tanda-tanda akhlak mulia pada seseorang, tanda-tanda orang yang tidak memiliki akhlak mulia, faktor-faktor yang menyebabkan adanya akhlak mulia, dan dampak akhlak mulia pada diri seseorang baik secara individu maupun sosial.

1. Pengertian Akhlak Mulia

Pengertian akhlak mulia menurut pandangan masyarakat sangat bervariasi dan beragam, dengan pengertian akhlak secara normatif oleh para ulama. Dari ketiga responden yang penulis wawancarai tentang akhlak mulia, mereka

${ }^{24}$ Zakiah Daradjat, Metodik Khusus Pengajaran Agama Islam..., hlm. 71.

${ }^{25}$ Wahbah Az-Zuhaili, Ensiklopedi Akhlak Muslim (Berakhlak dalam Bermasyarakat, terj. Abdul Azis, (Jakarta: Noura Books, 2014), hlm. xiv. 
memberikan penjelasan yang berbeda-beda. Untuk lebih detailnya berikut ini penulis paparkan hasil wawancara tentang pengertian akhlak mulia.

a. H. Sutaryo, SE., akhlak mulia, yaitu sifat yang mencakup semua jenis kebaikan, ketaatan dan amal. Ia memberikan contoh akhlak mulia, seperti sikap yang santun, sopan, tutur kata lembut penuh kasih sayang, tidak marah, bisa menjadi teladan yang baik, dan taat beribadah. ${ }^{26}$

b. H. Supadi, SH., pengertian akhlak mulia ialah perilaku rutinitas yang baik, yang terpuji dan bukan temporer, yang menjadi tuntunan agama maupun sosial kemasyarakatan. Ia menjelaskan bahwa akhlak mulia dasarnya adalah alQur'an dan Hadits. ${ }^{27}$

c. H. Nasucha, SE., pengertian akhlak yang mulia adalah perilaku baik seseorang berdasarkan iman yang kuat, baik kepada sesama muslim maupun kepada nonmuslim. Ia memberikan contoh akhlak mulia adalah berbuat jujur. ${ }^{28}$

2. Tanda-tanda adanya akhlak mulia

Pandangan masyarakat tentang tanda-tanda adanya akhlak mulia pada diri seseorang dapat dilihat dari hasil wawancara dengan responden:

a. H. Sutaryo, SE., menjelaskan tanda-tanda adanya akhlak mulia pada seseorang, yaitu; 1) baik kepada siapa saja, kenal atau pun tidak, 2) menahan nafsunya untuk berbuat jahat baik lisan maupun tangan, 3) bersabar ketika dizalimi orang lain, 4) tidak mudah tersinggung.

b. H. Supadi, SH., menjelaskan tanda-tanda adanya akhlak mulia pada seseorang, yaitu; 1) perilakunya diterima masyarakat umum, 2) setiap bertindak mempertimbangkan segi positif dan negatifnya, 3)

${ }^{26}$ Wawancara dilaksanakan pada tanggal 30 Juni 2014. H. Sutaryo, SE ialah Ketua Yayasan Miftahul Mubarok. Beliau Pegawai PNS Dinas Pariwisata Jawa Tengah.

${ }^{27}$ Wawancara pada tanggal 30 Juni 2014 dengan H. Supadi, SH. Beliau adalah Ketua Majlis Taklim Asmaul Husna Masjid Al-Mubarok, dan beliau adalah Pegawai PNS Sekretarias Dewan Propinsi Jawa Tengah.

${ }^{28}$ Wawacara pada tanggal 30 Juni 2014 dengan H. Nasucha, SE. Beliau Sekretaris Takmir Masjid Al-Mubarok Tlogosari, dan Pensiunan PLN Distribusi Jawa Tengah dan DIY. 
berbicara dan berbuat selalu berpedoman pada aturan, baik aturan agama, pemerintah, maupun masyarakat.

c. Sedangkan H. Nasucha, SE., menjelaskan tanda-tanda adanya akhlak mulia pada seseorang yaitu; 1) seseorang senang melakukan amal ibadah baik yang sunah maupun yang wajib, 2) senang melakukan hubungan yang baik dengan sesama manusia.

3. Tanda-tanda seseorang yang tidak memiliki akhlak mulia

Dalam pandangan masyarakat, tanda-tanda orang yang tidak memiliki akhlak mulia adalah;

a. Menurut H. Sutaryo, SE., menjelaskan; 1) bersikap menghalalkan cara untuk meraih sesuatu, 2) tidak kenal aturan, 3) tidak peduli dengan aturan yang ada, 4) mudah mengabaikan amal ibadah, e) selalu mengajak ke arah yang negatif pada siapapun.

b. Menurut H. Supadi,SH., menjelaskan tanda seseorang yang tidak memiliki akhlak mulia, yaitu; 1) senang bergaul dengan orang yang buruk perilakunya, 2) mudah melanggar aturan yang ada, 3) tidak memperhatikan kepentingan orang lain, 4) tidak mempedulikan aturan, baik aturan agama, pemerintah maupun orang lain.

c. Sedangkan menurut H. Nasucha, SE. menjelaskan tandatanda orang yang tidak memiliki akhlak mulia ialah; a) tidak punya rasa malu, b) menunjukkan sikap yang baik di muka umum, c) mudah melakukan perbuatan yang bertentangan dengan norma agama dan sosial, d) banyak berbicara tapi sedikit berbuat.

4. Faktor-faktor adanya akhlak mulia

Dalam pandangan masyarakat faktor-faktor adanya akhlak mulia adalah sebagai berikut;

a. Menurut H. Sutaryo, SE., menjelaskan faktor yang menyebabkan adanya akhlak mulia; 1) keturunan, 2) lingkungan pergaulan sejak kecil, 3) pembawaan 4) ilmu pengetahuan.

b. Menurut H. Supadi, SH., faktor yang menyebabkan adanya akhlak yang mulia ialah; 1) lingkungan keluarga, 2) pendidikan formal dan nonformal, 3) lingkungan masyarakat, 4) keturunan, dan 5) rutinitas ibadah. 
c. Sedangkan H. Nasucha, SE., menjelaskan faktor yang menyebabkan adanya akhlak mulia adalah; 1) kebiasaan melaksanakan amar ma'rüf nahi munkar, 2) kebiasaan beramal saleh, 3) membiasakan menghindari tingkah laku tercela.

5. Pengaruh akhlak mulia bagi seseorang.

Pengaruh akhlak mulia terhadap seseorang menurut pandangan masyarakat dapat dilihat dari hasil wawancara dengan responden, yaitu;

a. H. Sutaryo, SE. menjelaskan bahwa pengaruh akhlak mulia bagi individu ialah; a) jiwanya tenang, b) mendatangkan kebahagiaan dalam kesederhanaan, c) tidak stres, d) tidak khawatir, e) tidak memiliki rasa takut sekalipun dari segi ekonomi pas-pasan, f) sudah merasakan surga di dunia.

b. Sedangkan secara sosial, menurut H. Sutaryo, SE., pengaruh adanya akhlak mulia bagi seseorang ialah; a) di tempat kerja bisa kondusif, tidak ada rasa iri (hasad), dan tidak saling menjatuhkan, b) di lingkungan masyarakatnya bisa jadi teladan, dapat memfasilitasi, memberi jalan keluar, menciptakan kerukunan, tidak menimbulkan konflik, dan punya toleransi yang tinggi, c) dapat mempengaruhi karakter orang lain ke arah yang lebih baik, dan d) dapat mempengaruhi lingkungan menjadi lebih baik.

c. Sedangkan menurut H. Supadi, SH., bahwa pengaruh adanya akhlak mulia secara individu adalah; a) selalu berperilaku baik seperti jujur dan pikiran yang positif, b) dalam berbuat selalu mempertimbangkan manfaat dan madaratnya. Adapun secara sosial, pengaruh akhlak mulia bagi seseorang ialah; a) orang yang berakhlak mulia sangat dibutuhkan masyarakat terutama dalam keteladanan dan kepemimpinannya, b) masyarakat merasa senang kepadanya, c) memiliki tanggung jawab yang besar baik dalam keluarga, lingkungan kerja, maupun masyarakat.

d. Menurut H. Nasucha, SE., menjelaskan bahwa pengaruh akhlak mulia pada seseorang secara individu adalah; a) ibadahnya teratur, b) imannya terpelihara. Sedangkan 
secara sosial orang yang memiliki akhlak mulia maka tingkah lakunya selalu baik.

\section{E. Pembahasan}

1. Pengertian akhlak mulia.

Pengertian akhlak mulia menurut pandangan masyarakat menekankan pada perbuatan yang tampak secara lahiriah dan perbuatan yang dilakukan secara terus menerus, serta tidak temporer. Kemudian perilaku yang tampak dan terus menerus tersebut tidak dibedakan antara perbuatan akhlak dengan ibadah dan keimanan. Sehingga akhlak mulia menurut masyarakat adalah tingkah laku yang terpuji, yang baik dan dapat dilihat dari perbuatan sehari-hari, baik dalam hubungannya dengan ibadah maupun keimanan.

Di antara akhlak mulia adalah sikap yang santun, sopan, tutur kata lembut penuh kasih sayang, tidak marah, bisa menjadi teladan yang baik, taat beribadah, dan berbuat jujur. Adapun sumber akhlak adalah tuntunan al-Qur'an dan Hadis. Masyarakat melihat akhlak dari perbuatan yang tampak ditampilkan, melalui perkataan dan perbuatan, namun tidak melihat dari segi hakikat. Atau mereka baru mengungkapkan buah dari akhlak, itu juga masih sangat terbatas belum pada buah akhlak yang lengkap. Imam al-Gazali pun melihat ketika beliau menyusun konsep tentang akhlak.

Al-Gazali mencontohkannya, seperti kata Hasan Basri: "Kebagusan akhlak itu manis, memberi kelebihan dan mencegah kesakitan." ${ }^{29}$ dan Al-Wasiti berkata: "Akhlak yang bagus adalah tidak bertengkar dengan orang dan orang tiada bertengkar dengan dia, karena ma'rifatnya kepada Allah". Syaikh al-Kirmani berkata: "Akhlak yang baik ialah mencegah yang menyakitkan dan menanggung kesulitan". Sebagian dari mereka, kata al-Gazali, mengatakan: "orang yang berakhlak ialah yang dekat dengan manusia (karena bagus pergaulannya) dan asing tentang sesuatu di antara manusia itu (tiada rapat berhubungan)." ${ }^{\prime 3}$. Dan masih banyak lagi contoh yang dikemukakan al-Gazali, yang pada intinya, bahwa masyarakat bersamaan mengartikan dari segi perilaku

\footnotetext{
${ }^{29}$ Al-Gazali, Ihyà', 'Ulüm al-Dìn ..., hlm. 1033.

${ }^{30}$ Al-Gazali, Ihyà', 'Ulüm al-Dīn ...,hlm. 1033.
} 
yang dapat ditampilkan dan belum pada pengertian hakikatnya.

Hal tersebut diakui oleh al-Gazali, bahwa pengertian akhlak seperti itu (tersebut di atas) adalah banyak. Yaitu mengemukakan buah (hasil) dari kebagusan akhlak. Tidak dari kebagusan akhlak itu sendiri. Kemudian, tidak pula meliputi dengan semua buah itu. Dan mengungkapkan yang tertutup dari hakikat itu adalah lebih utama daripada menyalinkan kata-kata yang bermacam-macam itu. ${ }^{31}$

Akhlak mulia dalam pandangan masyarakat yang dilihat dari segi buah yang ditampilkan adalah sesuatu yang wajar. Akhlak (dalam pengertian hakikatnya) memiliki hubungan yang sangat erat dengan perbuatan lahiriah yang tampak, demikian sebaliknya perbuatan lahiriah dapat menunjukkan batinnya. Dan hal yang demikian diakui oleh al-Gazali, dan beliau mengatakan: "Maka jiwa yang terlihat dengan mata hati itu lebih besar nilainya, dibandingkan dengan tubuh yang terlihat dengan mata kepala. Oleh sebab itu, urusan jiwa diagungkan oleh Allah swt., dengan disandarkannya kepadaNya". ${ }^{32}$ Sebagaimana tertera dalam (Q.S. Säd: 71-72), Allah memberitahukan, bahwa jasad (tubuh) itu dihubungkan kepada tanah, sedang ruh (jiwa) dihubungkan kepada Tuhan

2. Tanda-tanda adanya akhlak mulia pada seseorang.

Menurut pandangan masyarakat, tanda-tanda adanya akhlak mulia pada seseorang dapat dilihat dari perilaku yang ditampilkan, yaitu perilaku yang baik. Perilaku baik tersebut berhubungan dengan ibadah dan muamalah dengan orang lain, serta cara melakukannya. Pandangan masyarakat tentang tanda akhlak mulia tersebut, sama dengan ketika mereka mengartikan pengertian akhlak, yaitu dilihat dari perbuatan yang tampak. Menurut penulis, hal ini sangat wajar, mengingat persoalan tanda adalah sesuatu yang dapat dibuktikan. Maka mereka mengukur itu dari perilaku yang dapat terlihat. Namun, mereka belum dapat membedakan antara perilaku ibadah dengan perilaku akhlak. Begitu juga penulis memaklumi, karena akhlak dalam prakteknya juga tidak dapat dipisahkan dengan perbuatan ibadah. Dalam

\footnotetext{
${ }^{31}$ Al-Gazali, Ihyà', 'Ulüm al-Dìn ...,hlm. 1034.

${ }^{32}$ Al-Gazali, Ihya', 'Ulüm al-Dìn ...,hlm. 1034.
} 
pembagiannya, terdapat akhlak kepada Allah yang dapat dibuktikan dengan praktik ibadah. Seharusnya praktik ibadah hendaknya dapat membuahkan akhlak yang mulia.

Pandangan masyarakat tentang tanda-tanda adanya akhlak mulia adalah sebagai berikut; a) baik kepada siapapun, kenal atau tidak, b) tidak berbuat jahat baik lisan maupun tangan, c) bersabar ketika dizalimi orang lain, d) tidak mudah tersinggung. e) perilakunya diterima masyarakat umum, f) setiap bertindak mempertimbangkan segi positif dan negatifnya, g) berbicara dan berbuat selalu berpedoman pada aturan, baik aturan agama, pemerintah, maupun masyarakat, dan h) senang melakukan ibadah sunah dan wajib.

Jadi, tanda seseorang memiliki akhlak mulia adalah tercermin dari sikap perilakunya yang baik dalam pergaulan dengan orang lain, baik perkataan maupun perbuatannya, dan keberadaannya diterima oleh lingkungan. Di samping itu, rajin menjalankan ibadah sebagai bentuk hubungan baik dengan Tuhannya.

3. Tanda-tanda tidak adanya akhlak mulia pada seseorang.

Berdasarkan pandangan masyarakat juga dapat dilihat dari perilaku yang ditampilkan. yaitu; a) bersikap menghalalkan cara untuk meraih sesuatu, b) tidak peduli dengan aturan yang ada, baik agama, pemerintah maupun masyarakat, c) mudah mengabaikan amal ibadah, d) selalu mengajak berbuat ke arah yang negatif pada siapapun, e) bergaul dengan orang yang buruk perilakunya, f) tidak memperhatikan kepentingan orang lain, g) tidak punya rasa malu melakukan perbuatan jelek, h) menunjukkan sikap yang baik di muka umum, i) mudah melakukan perbuatan yang bertentangan dengan norma agama dan sosial, dan j) banyak berbicara tapi sedikit berbuat.

Pandangan masyarakat terhadap akhlak pada seseorang, bahwa akhlak yang baik tidak akan dapat berada pada keadaan akhlak yang buruk. Jika seseorang memiliki akhlak yang baik, maka akhlak yang buruk akan berkurang, Begitu pula sebaliknya. Hal tersebut dapat dilihat dari pandangan masyarakat bahwa seluruh perilaku yang tidak berada pada tanda-tanda adanya akhlak mulia itu termasuk tanda-tanda tidak adanya akhlak mulia pada seseorang.

4. Faktor-faktor adanya akhlak mulia. 
Menurut pandangan masyarakat bahwa faktor-faktor adanya akhlak mulia pada seseorang adalah; a) keturunan, b) lingkungan keluarga dan masyarakat, c) pembawaan d) pendidikan formal dan nonformal, e) rutinitas ibadah, f) kebiasaan-kebiasaan, seperti melaksanakan amr ma'rüf nahy munkar, beramal saleh, dan menghindari tingkah laku tercela.

Masyarakat masih menganggap bahwa keturunan menjadi faktor yang sangat berpengaruh terhadap terbentuknya akhlak mulia. Sehingga anak yang dilahirkan dari orang tua yang saleh kemungkinan besar anak akan tumbuh dan berkembang menjadi anak yang saleh juga. Pandangan masyarakat tersebut adalah pandangan pada umumnya dan yang semestinya, tetapi dalam kenyataan tidak selalu demikian. Banyak contoh pula, orang tua yang saleh tetapi anaknya tidak saleh, dikarenakan pergaulan yang tidak mendukung. Demikian pula faktor pembawaan, bagi masyarakat dikatakan dapat mempengaruhi akhlak pula.

Adapun faktor yang lainnya, menurut masyarakat ialah; lingkungan keluarga dan masyarakat, pendidikan, pembiasaan, dan rutinitas menjalankan ibadah merupakan faktor yang sangat menentukan terbentuknya akhlak yang baik. Menurut penulis, pandangan tersebut merupakan pandangan yang positif, mengingat bahwa manusia adalah makhluk sosial yang kehidupannya tidak akan lepas dari orang lain, dan perilaku seseorang merupakan indikasi adanya proses interaksi (belajar) dengan lingkungan.

5. Pengaruh akhlak mulia bagi seseorang

Seseorang yang memiliki akhlak mulia akan berpengaruh pada perilakunya. Secara tidak langsung mereka memandang bahwa akhlak mulia adalah sifat baik yang telah tertanam pada diri seseorang. Jika seseorang telah memiliki akhlak yang baik, maka akan melahirkan perilaku yang baik dalam segala bidang dan menjadikan hidupnya tenang dan tenteram. Pengaruh akhlak baik itu dapat dilihat secara individual maupun sosial. Secara individual akhlak yang baik akan menjadikan seseorang: (a) jiwanya tenang, (b) merasakan kebahagiaan dalam kesederhanaan, (c) tidak stres, (d) tidak khawatir, (e) tidak memiliki rasa takut sekalipun dari segi ekonomi pas-pasan, (f) sudah merasakan surga di dunia. Sedangkan secara sosial orang yang memiliki akhlak mulia, 
akan merasakan keadaan; (a) di tempat kerja bisa kondusif, tidak ada rasa iri (hasad) dan tidak saling menjatuhkan, (b) di lingkungan masyarakatnya bisa jadi teladan, dapat memfasilitasi, memberi jalan keluar, menciptakan kerukunan, (c) tidak menimbulkan konflik dan punya toleransi yang tinggi, (d) dapat mempengaruhi karakter orang lain ke arah yang lebih baik, (e) dapat mempengaruhi lingkungan menjadi lebih baik, (f) berpikir positif (positive thinking), (g) dalam berbuat selalu mempertimbangkan manfaat dan madaratnya, (h) menjadi teladan dalam masyarakatnya, (i) disenangi oleh masyarakat, dan (j) memiliki tanggung jawab yang besar baik dalam keluarga, lingkungan kerja, maupun masyarakat.

\section{F. Penutup}

Pandangan masyarakat tentang akhlak mulia bahwa akhlak mulia dimaksudkan sebagai perilaku yang baik yang tampak melalui lisan dan perbuatan, serta selalu ada pada diri seseorang, dan tidak temporer. Tanda-tanda adanya akhlak mulia pada diri seseorang dapat dilihat dari perilaku sehari-harinya berkaitan hubungan dengan diri sendiri, Tuhan maupun masyarakat. Perilaku mereka selalu ingin berbuat kebaikan. Sebaliknya tandatanda orang yang tidak memiliki akhlak yang mulia kecenderungannya selalu berbuat kejelekan dan tidak segan-segan melanggar aturan. Faktor adanya akhlak mulia adalah keturunan, lingkungan, dan pendidikan baik formal maupun nonformal. Pengaruh adanya akhlak mulia pada seseorang, secara individu akan membawa ketenangan dan ketenteraman. Sedangkan secara sosial ia akan diterima oleh masyarakatnya dan mudah menyesuaikan diri dengan masyarakat.

\section{Kepustakaan}

Abdullah, M. Yatimin, Studi Akhlak dalam Perspektif Al-Quran, (Jakarta: Amzah, 2007).

Amin, Ahmad, Etika (Ilmu Akhlak), (Jakarta: Bulan Bintang, 1993).

Asmaran As, Pengantar Studi Akhlak, (Jakarta: Raja Grafindo Persada, 2002).

'Atha, Muhammad Abdul Qadir Ahmad, Makärim al-Akhlaq, (Beirut: Dar al-Kutub al-Ilmiyah, 1989). 
Al-Zuhaili, Wahbah, Ensiklopedi Akhlak Muslim: Berakhlak dalam Bermasyarakat, terj. Abdul AQzis, (Jakarta: Noura Books, 2014).

Daradjat, Zakiah, Metodik Khusus Pengajaran Agama Islam, (Jakarta: Bumi Aksara, 2008).

Ekosusilo, Madyo, Sistem Nilai Dalam Budaya Organisasi Sekolah pada Sekolah Unggul (Studi Multi Kasus di SMU Negeri 1, SMU Regina Pacis, dan SMU al-Islam 01 Surakarta), (Malang: Disertasi Universitas Negeri Malang, 2003).

Ghazali, Imam, Ihya' Ulumiddin, terj. Ismail Ya'kub, (Singapura : Pustaka Nasional, 2003).

Ibn Maskawaih, Abū Ali Ahmad bin Muhammad al-Ma'rūf, Kitāb Tahz̧dib al-Akhlāq wa Tathhïr al-A'raq, (Mesir: AlHusainiyah al-Misriyah, 1329 H.).

Muhni, Djuretna A. Imam, Moral \& Religi, (Yogyakarta: Kanisius. 1994).

Murni Djamal, Metodik Khusus Pengajaran Agama Islam, (Jakarta: Departemen Agama, 1984).

Quasem, M. Abul. Kamil, Etika Al-Ghazali: Etika Majemuk dalam Islam, terj. J. Mahyudin, (Bandung: Pustaka, 1988).

Rakhmat, Jalaluddin, Dahulukan Akhlak di Atas Fiqih, (Bandung: Mizan, 2007).

Shihab, M. Quraish, Tafsir al-Misbah, (Tangerang: Lentera Hati. 2005).

Suseno, Franz Magnis, Etika Dasar: Masalah-masalah Pokok Filsafat Moral, (Yogyakarta: Kanisius, 1987).

Zarkasyi, Hamid Fahmy, Peranan Masjid dalam Pendidikan Karakter (Akhlaq), (Semarang: Makalah Seminar, Masjid Baiturrahman, 2011).

Zuchdi, Darmiyati, Model Pendidikan Karakter Terintegrasi dalam Pembelajaran dan Pengembangan Kultur Sekolah, (Yogyakarta: UNY Press, 2011). 
